\title{
An Examination of the Chinese Students' Expectations and Their Fulfillments of These Expectations in U.S. Business Schools
}

\author{
Chiang-nan Chao ${ }^{1}$, Niall Hegarty ${ }^{1}$, John Angelidis ${ }^{1} \&$ Victor F. Lu ${ }^{1}$ \\ ${ }^{1}$ Tobin College of Business, St. John's University, New York, USA \\ Correspondence: Chiang-nan Chao, Tobin College of Business, St. John's University, New York, USA.
}

Received: June 2, 2016

Accepted: June 20, 2016

Online Published: August 28, 2016

doi:10.5430/irhe.v1n2p187

URL: http://dx.doi.org/10.5430/irhe.v1n2p187

\begin{abstract}
This study explores whether or not Chinese students have fulfilled their expectations while studying at American universities, so to gain a better understanding of Chinese students' expectations and consequently their fulfillments of their expectations. The results indicate that business education in America helps Chinese students fulfill their expectations and prepare them for becoming leaders in the future. The business educators can gain a better understanding of this population, therefore, provide a better service. This study offers not only an informational glimpse of how American business education helps young Chinese students, but also the potential impact on the emerging markets.
\end{abstract}

Keywords: business education, international education, international students, global education

\section{Introduction}

In the past ten years from $2005 / 06$ to $2014 / 15$, the total international students in the U.S. rose 526,670 to 974,926 , an increase of $73 \%$, while during the same period, the total Chinese students in the country rose from 62,582 to 304,040, representing a $386 \%$ increase, according to Open Door report (Report of Open Door, 2015). The U.S. is in the lead for attracting international students, as over $20 \%$ of the total international students, or about $4.8 \%$ of the total student enrollment in the U.S. These international students and their families spent about US\$30 billion in the U.S. in 2015, according OpenDoor Report (OpenDoor Report, 2015). Providing higher education for international students makes a significant contribution to the U.S. economy (OpenDoor Report, 2015). In New York State, for example, the portion of this contribution was about US\$3.7 billion, which accounts for over $10 \%$ of the national total contribution made by the international students in 2015. Attracting the best students from around the world has become a large and growing global export opportunity (Zawacki-Richter \& Bedenlier, 2015; Lumby \& Foskett; 2015 Top Markets Report). Conversely, countries that see their students study abroad normally hope that these students return home and contribute to their home economy.

While the U.S. has maintained its leading position for attracting international students, China has become the largest single source of international students. Chinese students make up a commanding 31 percent of all international students in the United States in 2015. This strong growth is likely to continue, presenting important export opportunities for U.S. colleges and universities (2015 Top Markets Report; Report of Open Door, 2015). Educators and researchers seek to better understand this phenomenon and identify effective ways to serve this population, not as an educational strategy, but also an international trade strategy. This research, through an empirical setting focuses on the Chinese business students' expectations, whether or not these students fulfill their expectations, in order to provide some insights and directions for educators, university administrators, and trade administrators.

\section{Review of Literature}

Chinese students and their parents look for high-quality education, particularly, international education. They make the U.S. No. 1 destination, not only because the U.S. has the capacity to absorb large numbers of international students and is one of the major English speaking countries, but also U.S. universities offer higher quality and a large variety of academic programs (Hefling, 2013). Students from China value U.S. colleges and universities for their high quality education that stresses interdisciplinary approaches, student participation and critical thinking. Businesses employers in China value U.S. degrees highly, while students' parents have the means to afford (Gates, 2012). Attending a U.S. institution of higher learning is a costly venture for Chinese families, more than $60 \%$ of whom privately fund students' 
costs. Unlike American students who are often eligible for in-state tuition rates, financial aid and numerous scholarships, most Chinese students pay full tuitions which could run about $\$ 200,000$ just for tuition and fees over four year period (Zhao, 2013). There has to date been little research on Chinese students' expectations for studying abroad (Wilkins, et al 2012). Meanwhile, many U.S. universities are facing an increasingly tough financial situation with a shortage of domestic students, a decrease in corporate support, and declines in government subsidies. In such a situation, Chinese students with money to spend may fill that financial gap (Joseph, 2012). China's rapid economic growth enables parents to fulfill their dream of sending their kids for higher education in the U.S. For this reason, educators and administrators in the U.S. are interested in understanding Chinese students' expectations to come to study in the U.S., and how they can help Chinese students to fulfill their expectations. Figure 1 presents the ten-year growth of Chinese students in the U.S., 2005-2015.

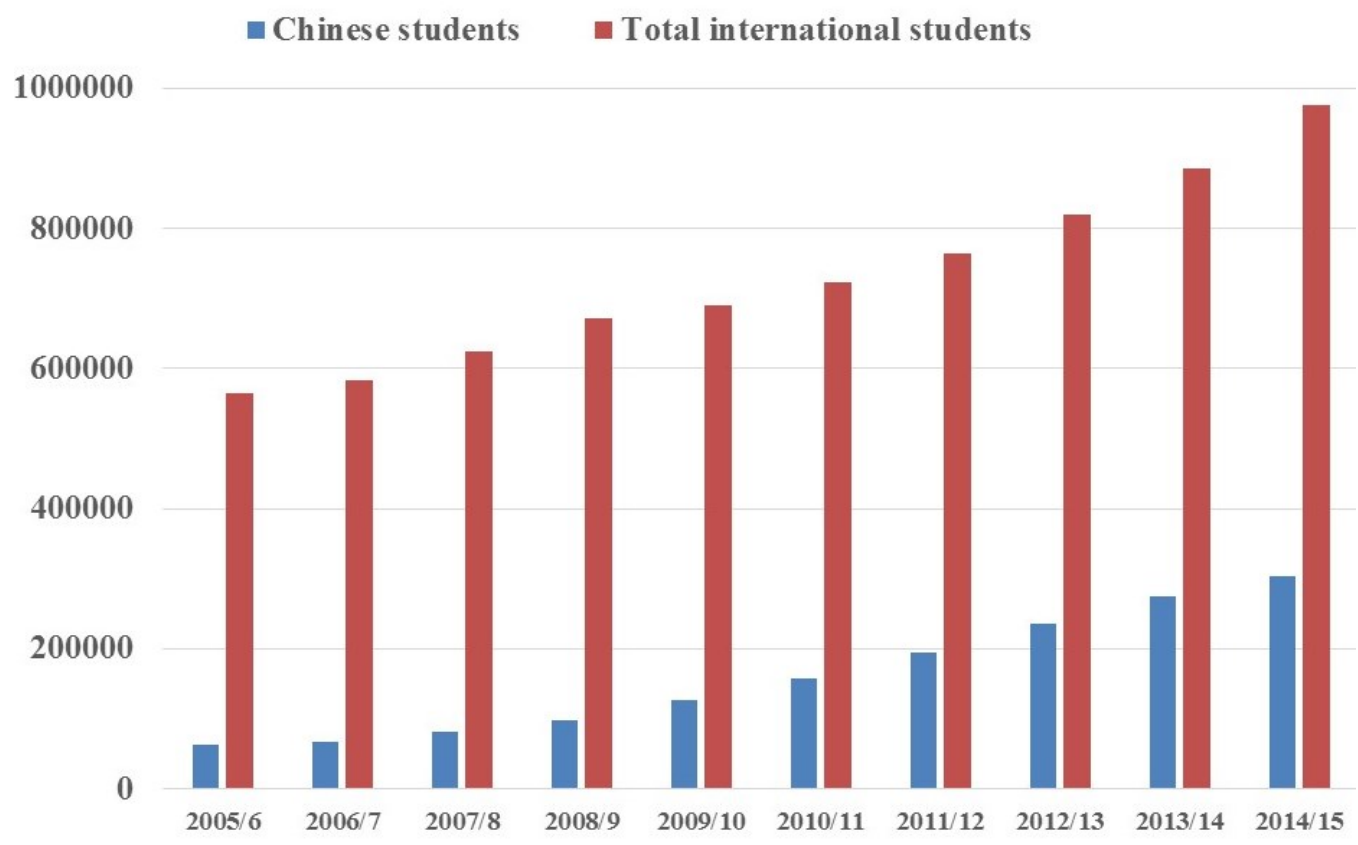

Figure 1. The Chinese students vs total int'l students in the U.S., 2005-2015

Source: Open Door,

2015. http://www.iie.org/Research-and-Publications/Open-Doors/Data/International-Students/Leading-Places-of-Origin/20 $13-15$

In China, high school students need to pass the Chinese national college entrance examinations to be admitted in Chinese colleges and universities. The Chinese national college entrance examinations are to be very competitive, but rigid. In the recent years, many believe that the Chinese educational system is corruptive (Wan, 2013). Chinese students and their parents judge U.S. schools to be a better choice for the higher education (Ark, et al 2008; Casiano, 2011; Fischer, 2012; Foadi, 2006; Korn, 2012; and Lee, 2012). While the benefits of studying abroad go beyond the degree itself. Several recent studies have investigated the motivations, incentives, and decisions for the Chinese students to study overseas. The study by Bodycott (2009) reveals that some foreign institutions have to understand not just the psychology and the expectations of Chinese students, but also those of their parents. The decisions and expectations may not be the only factors responsible for the choice leading Chinese students to decide to come to the U.S. A study by Bodycott (2009) focuses on the expectations of both parents and students. The study finds that parents' expectations are different from those of their children in terms of what they seek in a university with the range of programs available being the only common concern.

Glass (2012) suggests that international students who participate in leadership programs, community service, and campus-organized diversity discussions, interact with people from diverse cultural backgrounds, and take courses with materials on race and ethnicity report greater levels of learning and development. However, that study focused on learning outcomes rather than expectation factors leading international students to study in the U.S. 
The top fields of studies in the 2014/15 year, $26.5 \%$ of Chinese students in the U.S. are enrolled business/management, the fields better enable these students find employments in China (Ortiz, Chang, \& Fang, 2015). Figure 2 presents the major fields of study for the Chinese students in the U.S. (Source: http://www.iie.org/Research-and-Publications/Open-Doors/Data/International-Students/Fields-of-Study-Place-of-Ori $\operatorname{gin} / 2014-15)$.

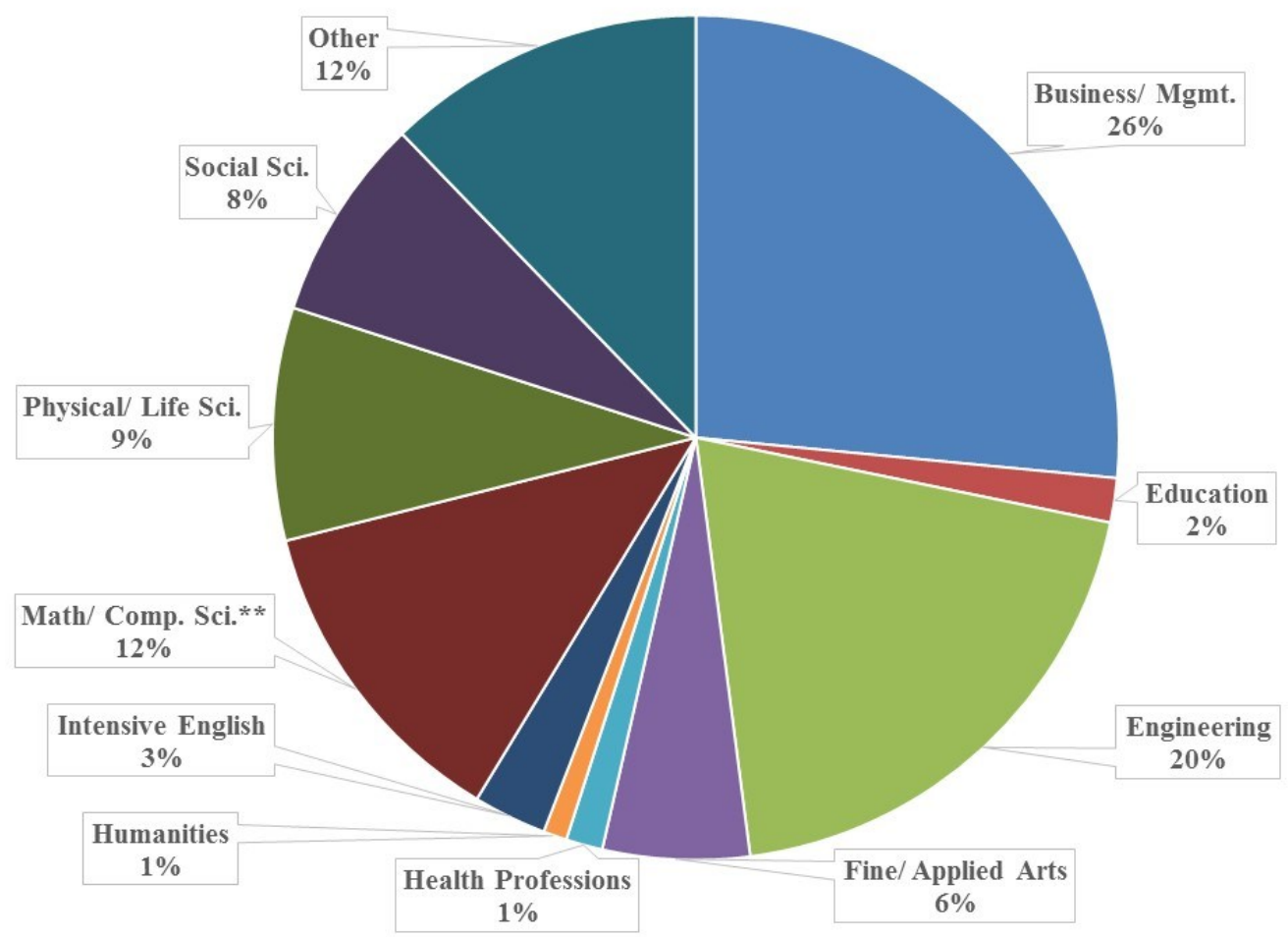

Figure. 2. Major fields of studies for Chinese students in the U.S., 2014-15

Source:

http://www.iie.org/Research-and-Publications/Open-Doors/Data/International-Students/Leading-Places-of-Origin/20 $14-15$

When looking into the Chinese applicants' backgrounds, many schools find some outstanding characteristics the Chinese applicants possess. First, many are China's best students who are probably aware that if they attend universities in China, they may not able to go to the best universities in the world. For example, among top 100 universities around the world, only two Chinese universities are ranked in 39th and 67th places by the U.S. News and World Report (Source: http://www.usnews.com/education/best-global-universities/rankings). Second, unlike U.S. institutions that value candidates who present themselves as unique, their Chinese counterparts want students who excel on entrance exams that require years of rote learning and possess a strong grasp of math and science. Third, these young individuals are ambitious and many want to go to Ivy League schools, a symbol for those parents who raise their children successfully. Fourth, they desire to learn more about critical thinking, and very importantly, they want to be exposed to things aside from just test taking (Henze \& Zhu, 2012; Taylor, 2012; Wu, 2014; Ruiz, 2014; Sorial \& Troisi, 2014).

The research work by Chao and Hegarty (2014) focuses on the Chinese students' motivations for attending colleges in the U.S. Their results indicate that Chinese students are seeking education with a global view and opt to break from the Chinese system of learning. The other research by Hegarty, et al (2014) explores decisions Chinese students make on whether or not to study in universities and colleges in the United States. Their research investigates the decision making process that leads to Chinese students to choose the United States as their preferred destination. Another study by Hegarty, et al (2014) explores the Chinese students' expectations for studying in the U.S. Their study offers a better understanding of how closely the reality of studying in the U.S. compared to these students' expectations. However, their study does not focus on business education, consequently, the weakness of their study 
throw light for this study: to explore the Chinese business students' expectations and their fulfillments of these expectations in US business schools.

\section{Methodology}

The purpose of this study was to examine Chinese business students' expectations for studying in the U.S. and the fulfillments of these expectations. A survey questionnaire was developed to examine expectations for studying in the U.S. and compare with the fulfillments of these expectations, with the following subcategories: demographics, selection criteria, application process, motivation to go abroad, expectations and accomplishments of these expectations. The literature reviews provide appropriate variables that can contribute to the body of knowledge required to understand of and service to this market segment.

\subsection{Variable Selection}

The following variables were selected as Chinese business students' expectations for studying in the U.S. The variables of the respondents' expectation are as the follows:

1). I expect to see the world and broaden my global experience.

2). I expect to improve my English communication skill while being with native speakers.

3). I expect to improve my professional skill in management in the U.S. business school.

4). I expect to improve my interpersonal skills with people with different backgrounds while in the U.S.

5). I expect that I can better control of my future.

6). I expect that I can learn how to develop business strategies in the U.S. business school.

7). I expect to learn more management skills in the U.S. business school.

8). I expect to earn a more valuable degree from a U.S. business school.

9). I expect to learn better quality business programs in U.S. business schools.

10). I expect to enjoy more freedom to select the courses and/or major I need for my own future in the U.S.business schools.

11). I expect that I can learn better technologies, i.e. computers and network in the U.S.

12). I expect to learn from qualified professors in the U.S. business schools.

13). I expect to learn critical thinking in the U.S. business schools.

The following fulfillment variables of their expectations are as the follows:

1). I have broadened my global experience.

2). I have improved my English communication skill while being with native speakers.

3). I have improved my professional skill in management in the U.S. business school.

4). I have improved my interpersonal skills with people with different backgrounds while in the U.S.

5). I believe that I can better control of my future.

6). I have learned how to develop business strategies in the U.S. business school.

7). I have learned more management skills in the U.S. business school.

8). I will earn a more valuable degree from the school I have enrolled.

9). I have learned better quality business programs in U.S. business schools.

10). I have enjoyed more freedom to select the courses and/or major I need for my own future in the U.S. business schools.

11). I have learned better technologies, i.e. computers and network in the U.S.

12). I have learned from qualified professors in the U.S. business schools.

13). I have learned critical thinking in the U.S. business schools.

The respondents were also asked whether or not they have fulfilled these expectations when they have been enrolled in a business degree program. The paired questions are as the follow: 


\subsection{Hypotheses}

The formulated research hypotheses for this study sought to find if there are any significant differences in Chinese students' expectations of studying in the U.S. and whether or not they have accomplished those expectations. The following hypotheses are formulated:

Hypothesis $_{1} \quad$ There is no significant difference between Chinese students' expectation to see the world and broaden his/her experience in the U.S. and what they have in the U.S.

Hypothesis $_{2} \quad$ There is no significant difference between Chinese students' expectation to learn English being in the U.S. and whether they have fulfilled this expectation in the U.S.

Hypothesis $_{3} \quad$ There is no significant difference between Chinese students' expectation to improve his/her professional and financial potential in the U.S. and what they have fulfilled in the U.S.

Hypothesis $_{4} \quad$ There is no significant difference between Chinese students' expectation to gain new insights and outlooks through new relationships in the U.S. and whether they have fulfilled this expectation in the U.S.

Hypothesis $_{5} \quad$ There is no significant difference between Chinese students' expectation to take control of his/her future in the U.S. and whether they have fulfilled this expectation in the U.S.

Hypothesis $_{6} \quad$ There is no significant difference between Chinese students' expectation to progress academically in schools in the U.S. and whether they have fulfilled this expectation in the U.S.

Hypothesis, There is no significant difference between Chinese students' expectation to develop skills in the U.S. and whether they have fulfilled this expectation in the U.S.

Hypothesiss There is no significant difference between Chinese students' expectation to earn a more valuable degree in the U.S. and whether they have fulfilled this expectation in the U.S.

Hypothesis, There is no significant difference between Chinese students' expectation to find better quality programs in schools in the U.S. and whether they have fulfilled this expectation in the U.S.

Hypothesis $_{10} \quad$ There is no significant difference between Chinese students' expectation to enjoy freedom in the U.S. and whether they have fulfilled this expectation in the U.S.

Hypothesis $_{11}$ There is no significant difference between Chinese students' expectation to enjoy better technology, i.e. computers and network abroad in the U.S. and whether they have fulfilled this expectation in the U.S.

Hypothesis $_{12}$ There is no significant difference between Chinese students' expectation to have more inspiring programs in schools in the U.S. and whether they have fulfilled this expectation in the U.S.

Hypothesis $_{13} \quad$ There is no significant difference between Chinese students' expectation to acquire critical more thinking in schools in the U.S. and what they have fulfilled this expectation in the U.S.

The alternate hypotheses are that significant differences exist between expectations and actual experience in the U.S.

\subsection{Sampling, Data Collection, and Measurements}

The research questionnaires distributed to Chinese business students in two universities in the North America. This sampling is convenient due to the exploration nature of the study.

A five point Likert scale was utilized with $5=$ most important, $4=$ important, $3=$ neutral, $2=$ not important, and $1=$ least important. Students were also asked to rate achievability of variables of expectations on a five point Likert scale, with $5=$ most fulfilled, $4=$ fulfilled, $3=$ =neutral, $2=$ not fulfilled, and $1=$ least fulfilled.

When two samples are involved and the values for each sample are collected from the same individuals (that is, each individual gives two values: one for each of the two categories), or the samples come from matched pairs of individuals, a paired-samples $t$-Test is an appropriate statistic to use. The paired samples $t$-Test can be used to determine if two means are different from each other when the two samples that the means are based on were taken from the matched individuals or the same individuals. The paired samples $t$-Test used compared the means of two variables. This procedure allowed the computation of the difference between the two variables for each case, and tests to see if the average difference is significantly different from zero, assuming that both variables should be normally distributed. The nulls are rejected if the significance levels are less than or equal to ten percent of the criteria, in other words, ten percent of the paired sample $t$-Test two-tailed probability level signifies the differences in effectiveness between the expectations and fulfillments of these expectations (Conover, 1980; Davis \& Cosenza, 1985; Hamburg, 1977; SPSS ${ }^{\mathrm{X}}$, 2002). So, for this research a $10 \%$ significance level was set to reject the null hypotheses. 


\section{Results}

Over 350 respondents were surveyed, with 128 completed responded for analyses, representing 36.5 percent of the total surveyed. Table 1 presents the general background information of the respondents.

Table 1. Backgrounds of the respondents

\begin{tabular}{lcc}
\hline Variables & Groups & Valid \% \\
1. Age & $<18$ & 6.4 \\
& $18-35$ & 92.0 \\
2. gender & $>35$ & 1.6 \\
3. Family annual income & Male & 56.0 \\
& Female & 44.0 \\
4. Education & $<\$ 30 \mathrm{k}$ & 33.9 \\
& $\$ 30-50 \mathrm{k}$ & 26.4 \\
5. Marital status & $\$ 50-75 \mathrm{k}$ & 13.7 \\
& $>\$ 75 \mathrm{k}$ & 25.8 \\
6. Sources of financial supports & College & 69.6 \\
& Graduate & 30.4 \\
& Married & 9.6 \\
& Single & 90.4 \\
7. If you took Gaokao, you stood at & Parent & 56.8 \\
& Own saving & 5.6 \\
& Obtained scholarship or GA & 22.4 \\
& Combination of various sources & 15.2
\end{tabular}

Source: original

It is noticeable that roughly a third of the Chinese business students who took the survey has an annual family income over US\$75K equivalent, and most of the students were born after 1978 when one child per family policy was initiated (Source: http://healthland.time.com/2013/01/10/little-emperors/). Over 97 percent of the respondents took College entrance-exams and stood at the top 50 percent, while currently, over 50 percent of Chinese high school graduates are able to go to college in China. In comparison, in the U.S. over 70 percent of the high school graduates go to college (Source: http://www.bls.gov/news.release/hsgec.nr0.htm; Source: http://zhidao.baidu.com/question/57277001.html). In another word, these respondents had alternatives for their college selections: either stay in China or go to the U.S. Table 2 presents the Chinese students' application considerations with the highest mean ranking of the top. 
Table 2. Chinese student application considerations

scale: $1=$ least important, $5=$ most important.

\begin{tabular}{lc}
\hline Variables to consider & Mean \\
Top 100 schools & 3.58 \\
Accredited schools & 3.41 \\
Private schools & 2.98 \\
Any school that accepts me & 2.48 \\
Public schools & 2.41 \\
Offer distance learning so that one can stay in China & 2.09 \\
Community colleges & 1.88 \\
\hline
\end{tabular}

Source: original

The respondents give high marks to two consideration variables: top 100 schools and accredited schools. While they believe these variables are less important: Public schools, Private schools, Offer distance learning so that one can stay in China, and Any school that accepts me. The respondents give the lowest rating for Community colleges. Table 3 illustrates how Chinese applicants search for information about universities they plan to apply with the highest mean ranking of the top.

Table 3. How Chinese students search information for their applications

scale: $1=$ least important, $5=$ most important.

\begin{tabular}{lc}
\hline Variables & Mean \\
Search all information by yourself & 3.78 \\
Obtain funds to pay for tuitions and fees & 3.46 \\
With help of your friends and relatives & 3.40 \\
With the help of schools you applied & 3.10 \\
Obtain visa to the country you want to go & 3.04 \\
Rely on an agency & 2.47 \\
\hline
\end{tabular}

Source: original

The respondents give high importance marks on the information search variables: Search all information by himself/herself, Obtain funds to pay for tuitions and fees, and with help of your friends and relatives. They give these variables about average scores: With the help of schools you applied and Obtain visa to the country you want to go. As one of the authors observed while travelling in China, there are a numerous for profit agencies in most of the major cities and on the web, however, the respondents in the survey give this variable a low importance rating. Table 4 presents the results of the comparisons between the Chinese students' expectations and achievability of these expectations in the paired samples $t$-Test results, with paired mean difference, $t$ values, degrees of freedom, and significance of the tests. 
Table 4. The paired samples $t$-Tests and 2-tailed significance of $t$, valid $\mathrm{n}=115$

\begin{tabular}{|c|c|c|c|c|}
\hline Variables & $\begin{array}{l}\text { Mean } \\
\text { Dif }\end{array}$ & $\begin{array}{l}\text { Std. } \\
\text { Dev }\end{array}$ & $t$ & Sig. \\
\hline Broaden my global experience. & -0.035 & 0.999 & -0.373 & 0.710 \\
\hline $\begin{array}{l}\text { Improve my English communication skill while being with native } \\
\text { speakers. }\end{array}$ & -0.054 & 1.244 & -0.456 & 0.649 \\
\hline $\begin{array}{l}\text { Improve my professional skill in management in the U.S. business } \\
\text { school. }\end{array}$ & 0.114 & 1.158 & 1.051 & 0.295 \\
\hline $\begin{array}{l}\text { Improve my interpersonal skills with people with different backgrounds } \\
\text { while in the U.S. }\end{array}$ & 0.009 & 1.212 & 0.078 & 0.938 \\
\hline Better control of my future. & 0.257 & 1.148 & $\mathbf{2 . 3 7 7}$ & 0.019 \\
\hline Develop business strategies in the U.S. business school. & -0.054 & 1.153 & -0.492 & 0.624 \\
\hline Learn more management skills in the U.S. business school. & 0.064 & 1.160 & 0.576 & 0.566 \\
\hline Earn a more valuable degree from the school I have enrolled. & -0.018 & 1.147 & -0.167 & 0.868 \\
\hline Learn better quality business programs in U.S. business schools. & -0.108 & 1.003 & -1.135 & 0.259 \\
\hline $\begin{array}{l}\text { Enjoy more freedom to select the courses and/or major I need for my own } \\
\text { future in the U.S. business schools. }\end{array}$ & -0.062 & 1.182 & -0.557 & 0.579 \\
\hline Learn better technologies, i.e. computers and network in the U.S. & -0.204 & 1.174 & -1.843 & 0.068 \\
\hline Learn from qualified professors in the U.S. business schools. & -0.027 & 1.078 & -0.263 & 0.793 \\
\hline Learn critical thinking in the U.S. business schools. & -0.080 & 0.941 & -0.904 & 0.368 \\
\hline
\end{tabular}

Source: original

\section{Conclusion}

The mean differences are calculated by the mean of the expectation variable minus the paired mean of the degree of achievements of these expectations. A positive mean difference shows that the respondents fulfilled less than their expectations, while a negative mean difference implies that the respondents fulfilled more than they expected. The test results of the Paired Sample $t$-Tests show significance levels less than $10 \%$ in two null hypotheses: Better control of my future, and Learn better technologies, i.e. computers and network in the U.S. business schools. Therefore, these two hypotheses are rejected. For the variable Better control of my future, a positive mean difference indicates that the respondents are less certain about the future, as some respondents indicate that the world is full of uncertainties when they come to the U.S. The variable Learn better technologies, a large negative mean difference indicate the respondent weigh more they have fulfilled.

With regard to the other eleven variables: Broaden my global experience, Improve my English communication skill while being with native speakers, Improve my professional skill in management in the U.S. business school, Improve my interpersonal skills with people with different backgrounds while in the U.S., Develop business strategies in the U.S. business school, Learn more management skills in the U.S. business school, Earn a more valuable degree from the school I have enrolled, Learn better quality business programs in U.S. business schools, Enjoy more freedom to select the courses and/or major I need for my own future in the U.S. business schools, Learn from qualified professors in the U.S. business schools, Learn critical thinking in the U.S. business schools, the null hypotheses are accepted. The insignificances of these test results should suggest that there are no significant differences between respondents' expectation and their achievement while studying in universities in the U.S.

This study can conclude from these research results that Chinese business students' expectations in the U.S. have mostly fulfilled. This research also shows that Chinese students' fulfillments of their expectations further motivate the Chinese high school kids to seek for quality business programs in the U.S. These expectations are consistently with attitudes of affluent middle classes who have moved beyond daily sustenance and have fulfilled security. More importantly, the respondents show that they achieve significantly more than they expect. These driving expectations will sustain the Chinese student enrollment growth in the U.S. in the future. 
The study suggests that universities and colleges in the U.S., not only business schools, need to recognize the diversity of Chinese students' expectations in order to continuously improve the quality of business education not only for Chinese students, but also for other international students. In addition, the study suggests that universities and colleges in the U.S. need to adapt to the changing expectations of the Chinese students. A great number of universities' websites for recruitment is designed during the pre-social network era and may not be as effective as they used to be. Many Chinese students and their families use popular "wechat", an equivalent to Facebook or Twitter. Simply speaking, some universities' administrators do not have a desire to explore this integration of their traditional recruiting strategies with the newly emerged social network. Furthermore, the study recommends universities in the U.S. to investigate other Chinese students' expectations and achievements of these expectations.

In line with the purpose of this exploratory research, one concern is that the rapid growth of the Chinese students' enrollment in the U.S. will not last forever. When many of the Chinese Ph.D. graduates from the U.S. return and work in Chinese universities, they would bring the higher quality of business education to China. So it is inevitable a gradual shrinkage of the Chinese student enrollment in the U.S. colleges and university ten years from now.

\section{Limitations and Future Research}

This research, while the sample is limited to only two universities, although it does provide some glimpses and insights for subsequent research to consider. The sample size is small due its exploratory nature. There are additional unknowns that require further research work, as the available research on the expectations and fulfillments of these expectations by international students in the U.S. is limited.

The this study has uncovered many instances where universities are facilitating international students' expectations and work tirelessly to enable these students to fulfill their expectations, there remains a lack of front-end empirical research on the understanding of the how and why Chinese students arrive at the decision to study in the U.S. It is advisable that future researches explore this gap in the students' expectation and their fulfillments of these expectations. Only then will colleges and universities have a full picture of the incoming student population.

In the process of this research, in-depth discussions with many of Chinese business students as to whether or not the host universities has served them well, and what improvements need to be made. Many Chinese students have expressed some reservations, i.e. in some MBA course, over 70\% students come from China, and often Chinese is spoken in class discussions, therefore, the Chinese students have limited opportunities to speak English.

To facilitate data collection, international student service offices would be ideal locations by which to administer questionnaires to maximize the sample. There may be the need to compare Chinese students in public versus private universities. Another future direction may focus on two groups of students, graduates vs undergraduates.

In a final analysis, the total fulfillments of the Chinese students' expectations lay in the future when these students complete their study and work in their careers - that is a real test.

\section{References}

2015 Top Markets Report, Education--A Market Assessment Tool for U.S. Exporters, Industry \& Analysis (I\&A), International Trade Administration, U.S. Department of Commerce, 2015. Retrieved from http://trade.gov/topmarkets/

Ark, B. V., O'Mahony, M., \& Timmer, M. P. (2008). The Productivity Gap between Europe and the United States: Trends and Causes. Journal of Economic Perspectives, 22(1), 25-44.

Bodycott, P. (2009). Choosing a Higher Education Study Abroad Destination. Journal of Research in International Education, 8(3), 349-73.

Casiano, M. A. (2011). U.S. Economy Shows Continuing Signs of Strength. Caribbean Business, March 3.

Chao, C., \& Hegarty, N. (2014). Driving Forces which Enthuse the Continuous Growth of Chinese Students in U.S. Colleges: A Preliminary Study on Chinese Students' Motives. Journal of Academic Administration in Higher Education, Fall, 10(2), 27-34.

Conover, W. J. (1980). Practical Nonparametric Statistics (2nd ed.). New York: John Wiley \& Sons, pp. 213-337, pp. 344-384.

Davis, D., \& Cosenza R. M. (1985). Business Research for Decision Making. Boston: Kent Publishing.

Fischer, K. (2012). Chinese Students Account for About Half of All International Applicants to U.S. Graduate Programs. The Chronicle of Higher Education, April 3. 
Foadi, S. M. (2006). Key Issues and Causes of the Italian Brain Drain. The European Journal of Social Sciences, 19(2), 209-223.

Gates, M. (2012). China's growing middle class means influx of students for U.S. colleges. USA Today, January 11.

Glass, C. R. (2012, July). Educational Experiences Associated With International Students' Learning, Development, and Positive Perceptions of Campus Climate. Journal of Studies in International Education, 16, 228-251.

Hamburg, M. (1977). Statistical Analysis for Decision Making (2nd ed.). Harcourt Brace Jovanovich, Inc., New York, pp. 219-538.

Hefling, K. (2013). Study: Record number of foreign students hit US. Associated Press, November 11.

Hegarty, N., Fuxman, L., Elifoglu, I. H., \& Chao, C. (2014). An Investigation on whether or not Chinese Students Have Achieved their Expectations to Study in U.S. Universities? International Journal of Education Research, Spring, 9(1), 163-176.

Hegarty, N., Fuxman, L., Elifoglu, I. H., \& Chao, C. (2014). Chinese Students' Decisions for Studying in U.S. Colleges: An Exploratory Investigation. Review of Business, 34(1), 81-90.

Joseph, F. (2012). Overseas colleges fight for Chinese students. CNTV, October 19.

Korn, M. (2012). Change in GMAT Equation: Chinese Flock to the Test. the Wall Street Journal, September 23, 2012.

Lee, E. (2012). Number of Chinese Students in US Dramatically Expands. Voice of America, October 12.

Lumby, J., \& Foskett, N. (2015). Internationalization and Culture in Higher Education. Journal of Studies in International Education, January 16.

Report of Open Door. (2015). Retrieved from http://www.iie.org/Research-and-Publications/Open-Doors/Data/International-Students/Enrollment-Trends/194 $8-2014$

Retrieved from http://healthland.time.com/2013/01/10/little-emperors/

Retrieved from http://www.bls.gov/news.release/hsgec.nr0.htm

Retrieved from http://www.iie.org/Research-and-Publications/Open-Doors/Data/International-Students/Leading-Places-of-Origi $\mathrm{n} / 2013-15$

Retrieved from http://www.iie.org/Research-and-Publications/Open-Doors/Data/International-Students/Fields-of-Study-Place-o f-Origin/2014-15

Retrieved from http://zhidao.baidu.com/question/57277001.html

SPSS $^{\mathrm{X}}$, Advanced Statistics, 7.5. Chicago, IL: SPSS Inc. 2002.

Wan, W. (2013). In China, parents bribe to get students into top schools, despite campaign against corruption. Washington Post, October 7.

Wilkins, S., Balakrishnan, M. S., \& Huisman, J. (2012, November). Student Choice in Higher Education: Motivations for Choosing to Study at an International Branch Campus. Journal of Studies in International Education, 16, 413-433.

Zawacki-Richter, O., \& Bedenlier, S. (2015, June). Internationalization of higher education and the impacts on academic faculty members. Journal of Studies in International Education, 10, 185-201.

Zhao, E. (2013). Chinese Students Struggle for Returns on Education in U.S.. China Real Time, March 27. 